\title{
DISKUSSIE 4
}

Prof. J. H. van Wyk vestig die aandag op 'n klein brosjure van groot waarde, uitgegee deur die Gereformeerde predikante van Potchefstroom, saamgestel deur dr. C. F. C. Coetzee:

Is hierdie geeste van God afkomstig?: Twee nuwe Pinkstergroepe in Potchefstroom.

In hierdie brosjure word aandag bestee aan die ontstaan van die Logos-Instituut en die Humnos-Baptiste. Hulle beskouinge rondom die Gees en geestesgawes, kinderdoop en geloof word bespreek en weerlê. Uit die styl is dit duidelik dat dit 'n strydgeskrif is in 'n konkrete situasie, dus soms met skerp formulering, en daarom moet dit as sodanig beoordeel word.

Juis omdat ek hierdie brosjure van soveel waarde ag en vir wye verspreiding aanbeveel, wil ek graag enkele suggesties aan die skrywers deurgee wat by 'n herdruk in ag geneem kan word.

Die eerste suggestie handel oor die verhouding tussen Woord en Gees. Op bl. 7 word gesê: "Hierteenoor leer die Skrif juis dat die Heilige Gees nooit los van die Woord werk nie (vgl. o.a. Joh. 14:26, Hand. $2: 37$, Rom. $10: 14$ )".

Dogmaties besien is hierdie stelling meer Luthers (per verpum) as Calvyns (cum verbo). Hoewel Calvyn baie duidelik die besonder noue band tussen Woord en Gees beklemtoon het, wou hy tog nooit die Gees 'n gevangene van die Woord maak nie en het hy geleer dat die Gees soms ook buite die prediking van die Woord werksaam kan wees en kennis van God kan skenk (Institusie IV 16:19). In die reél werk die Gees egter deur die Woord (vgl hier slegs Jonker WD, 1981, Die Gees van Christus, Pretoria, 50-58).

Bogenoemde stelling moet dus myns insiens ietwat meer genuanseer word.

'n Tweede stelling waar herformulering oorweeg kan word staan op bl. 10 en lui: "Dit is eenvoudig logies om te aanvaar dat daar wel ook kinders onder hierdie mense (huisgesinne) was". Die argument van die huisgesindoop veronderstel dat daar klein kindertjies teenwoordig was en gedoop is, en inderdaad is dit ' $n$ argument, maar 'n beskeie argument (argumentum $e$ silentio). In die NGB art 34 en HK 27:74 asook in die Doopsformulier funksioneer dit eintlik nie. Die "dit is logies" moet dus versag word om as 'n meer beskeie argument te funksioneer - want dit bly 'n argument, aangesien diegene wat die kinderdoop verwerp, moet veronderstel dat in die geval van die vyf huisgesinsdope geen kinders gedoop is nie.

Hierby kan myns insiens ook nog die sterk argument gevoeg word dat, soos wat daar in die NT geen direkte teks vir die kinderdoop is nie, so is daar in die NT ook geen enkele direkte teks vir die grootdoop van kinders wat uit gelowige ouers gebore is nie (vgl. König, A. (red). 1979, Strydgesprek oor die Kinderdoop, Pretoria, 12,33 ).

Derdens sou ek wou aanbeveel dat die titel herformuleer word om minder persoonlik en meer saaklik te wees.

Hierdie brosjure, soos ook die van L. Floor oor Kinderdoop, 
Grootdoop, Herdoop (Jan 1983, IRS, Potchefstroom), kan vir lidmate van groot waarde wees vir geloofsuiwerheid en geloofsverryking. Ek wil graaf, aanbeveel dat dit 'n wye leserkring sal vind .

In De Reformatie van 6 Nov. 1982 verskyn daar 'n interessante berig van J. D (ouma) oor die kerklike lewe. Hy skryf daarin oor die konstituerende vergadering van die nuwe ekumeniese liggaam nl. die International Conference of Reformed Churches. Hy verwys in sy artikel na 'n voorstel van ds. J. Kapteijn uit SA dat in die statute van die ICRC ' $n$ bepaling ingesluit sou word waarin dit onmoontlik gemaak word om twee kerke wat in een land langs mekaar lewe, beide op te neem. Hierop het 'n Ierse afgevaardigde, rev. D. W. H. Thomas, gereageer deur te sê dat hy dan nie meer sal kan meedoen nie aangesien sy kerke 'n broederlike verhouding met 'n ander kerk in Noord-Ierland onderhou.

Douma ag die vraag van ds. Kapteijn ter sake maar is tog dankbaar dat ' $n$ derglike bepaling nie in die statute opgeneem is nie. Dan volg 'n baie veelseggende uitspraak. "Dat er dan twee ware kerken naast elkaar bestaan, is mogelijk. Maar dat ze naast elkaar en los van elkaar blijven bestaan, is te veroordelen. Wat éen is, moet zich ook als één openbaren".

Ek vereenselwig my met hierdie uitspraak van Douma. 